\title{
Law and the Exclusionary Essence of Large-Scale Investments in Sub-Saharan Africa Land
}

\author{
Tomaso Ferrando* \\ Sciences Po Law School, Paris, France
}

\begin{abstract}
'Global land grabbing' represents one of the hottest topics of debate within the areas of developmental and agricultural studies. However, this article claims that a narrow focus on the illegality and consequences of the 'grabbing', rather than on large scale investments in land (LaSIL) as a form of economic development which is inherently exclusionary, can be detrimental to the future of small-scale farmers. A short-term perspective overlooks the indirect consequences of industrialization, and legitimizes longterm exclusions and marginalization. Through past and present evidence, this paper demonstrates that LaSIL as competing projects will inevitably produce the abandonment of rural areas, the proletarianization of peasants, and the increase in social inequality, against any possibility for coexistence and harmonious cooperation.
\end{abstract}

Keywords

Large scale investments in sub-Saharan African land; land grabbing; investment law; legal remedies; human rights

\section{Introduction}

According to the contested and prudential data which have been recently published by the Land Matrix Initiative, ${ }^{1}$ more than 80 million hectares of land all over the world have been already enclosed by national and foreign investors, mainly with the intention to produce cash crops, flexi-crops and, in a lower

*) E-mail: tomaso.ferrando@sciences-po.org. Tomaso Ferrando is a PhD Candidate in Law at Sciences Po Law School, in Paris, where he works under the supervision of Prof. Horatia Muir Watt and Prof. JeanPhilippe Robé. Tomaso is currently visiting researcher at the Commercial Law Department, Universidade de São Paulo, Brazil, and was recently Visiting Researcher at the Public Law Department, University of Cape Town, South Africa. His doctoral research focuses on the interactions between state sovereignty and global capital, with particular attention to the legal mechanisms and the institutions that intervene to define the limits, rights, duties, and impact of these relations. He has also worked as consultant for international NGOs, and is actively involved in actions of legal resistance against grabbing in Cameroon.

1) W. Anseeuw, J. Lay, P. Messerli, M. Giger and M. Taylor, 'Creating a public tool to assess and promote transparency in global land deals: the experience of the Land Matrix', 40 Journal of Peasant Studies (2013), 521-530; M. Edelman, 'Messy hectares: questions about the epistemology of land grabbing data', 40 Journal of Peasant Studies (2013), 485-501; C. Oya, "Methodological reflections on "land grab" databases and the "land grab" literature "rush"', 40 Journal of Peasant Studies (2013), 503-520. 
percentage, food. In particular, the geographical distribution of the investments demonstrate that this phenomenon, which has been defined as land grabbing, ${ }^{2}$ 'green rush,'3 'neo-colonialism' or 'a new scramble for Africa', is mainly targeting Africa and Low Income Countries. Of the 83.2 million hectares of land that have been targeted in developing countries, in fact, 56.2 million are located in Africa, 17.7 million in Asia and 7 million in Latin America. Therefore, the problem is real and in continuous expansion, and sub-Saharan Africa is at its core.

The global competition for African resources undoubtedly represents a theme which has been object of a wide debated, mainly for its negative impacts on the availability of resources, the appropriation of traditional land, the use of arable land to produce agrofuels, ${ }^{4}$ and for the transfer of resources from peripheral countries to the core. However, while several authors have focused on the loss of arable land, on direct evictions, and on the grabbing of fresh water from the local communities, ${ }^{5}$ little attention has been paid on the impact that this 21st-century enclosure can have in producing indirect displacement and, in some cases, international migrations.

For example, while the International Organization for the Migrations has started looking at environment-led migrations, no documents or reports have been released on the relationship between the current agricultural development and the production of cross-boundaries fluxes. Similarly, the attention of politicians and legal practitioners is always on the direct impact over rural population and the risk of expropriations and evictions, while no attention is paid to

\footnotetext{
2) S.M. Borras, J.C. Franco and C. Wang, 'The Challenge of Global Governance of Land Grabbing: Changing International Agricultural Context and Competing Political Views and Strategies', 10 Globalizations (2013), 161-179; S.M. Borras, J.C. Franco, S. Gómez, C. Kay and Max Spoor, 'Land grabbing in Latin America and the Caribbean', 39Journal of Peasant Studies (2012), 845-872; J. Franco, L. Levidow, D. Fig, L. Goldfarb, M. Hönicke and M.L. Mendonça, 'Assumptions in the European Union biofuels policy: frictions with experiences in Germany, Brazil and Mozambique', 37 Journal of Peasant Studies (2010), 661-698; O. De Schutter, 'How not to think of land-grabbing: three critiques of large-scale investments in farmland', 38 Journal of Peasant Studies (2011) 249-279; F. Makki, 'Power and property: commercialization, enclosures, and the transformation of agrarian relations in Ethiopia', 39Journal of Peasant Studies (2012), 81-104.

3) O. De Schutter, 'The green rush: The Global Race for Farmland and the Rights of Land Users', 52 Harvard International Law Journal (2011), 504-561.

4) J. Baka, 'The Political Construction of Wasteland: Governmentality, Land Acquisition and Social Inequality in South India', 44 Development and Change (2013), 409-428; P. Dauvergne and K.J. Neville, 'Forests, food, and fuel in the tropics: the uneven social and ecological consequences of the emerging political economy of biofuels', 37 Journal of Peasant Studies (2010), 631-66o; C. Hunsberger, 'The politics of Jatropha-based biofuels in Kenya: convergence and divergence among NGOs, donors, government officials and farmers', 37 Journal of Peasant Studies (2010), 939-962; R.A. Nalepa and D.M. Bauer, 'Marginal lands: the role of remote sensing in constructing landscapes for agrofuel development', 39Journal of Peasant Studies (2012), 403-422.

5) P. Woodhouse, 'New investment, old challenges. Land deals and the water constraint in African agriculture', 39 Journal of Peasant Studies (2012) 777-794; Borras, Franco and Wang, supra note 2; L. Cotula, 'The international political economy of the global land rush: A critical appraisal of trends, scale, geography and drivers', 39 Journal of Peasant Studies (2012), 649-680; K. Deininger, 'Challenges posed by the new wave of farmland investment', 38 Journal of Peasant Studies (2011), 217-247.
} 
the indirect consequences of a modernization process in terms of competition between incumbents and new comers for land, water and the market.

In this framework, the aim of the present paper is to start filling this gap, first of all by affirming that in many cases large-scale investments in land (LaSIL) are conducted by directly evicting people and generating unplanned migrations. Secondly, I also look at how sovereignty and law are utilized to endorse and support developmental strategies that will significantly increase the existent human pressure over cities and national frontiers, along with inequality between newly born proletarians and capitalists, and social unrest.

Entrapped in the asymmetrical struggle between the territoriality of sovereignty and the mobility of capital, ${ }^{6}$ states face a situation that I define elsewhere the sovereigns' dilemma, and eventually utilize their authority to facilitate foreign investors, who are looking for land where delocalize the alimentary and energetic production of core countries. However, the satisfaction of foreign needs by using Sub Saharan land comes at the cost of displacement, urbanization, and international mobility, three circumstances that appear incompatible with the theory of inclusive and sustainable development which lies behind the generalized and institutional support to LaSIL as a mechanism of poverty alleviation. ${ }^{7}$

Against this background, this article proceeds as follows. Sections 2 to 4 present cases of direct eviction of people linked to the realization of large scale investments in occupied public land, stressing the role that law plays in shaping and legitimizing these anti-poor actions. Section 5 defines large scale investments in land as inherently exclusionary, so to demonstrate their incompatibility with the continuance of rural livelihood and consider the indirect pressure that they exercise toward the abandonment of rural areas. Finally, the last Section is dedicated to the critical analysis of some existing legal remedies that have been proposed as defence against evictions, and to the endorsement of the Pan-African Parliament's call for an immediate moratorium.

\section{Sovereignty between Inclusion and Exclusion}

Mark Twain, an American humorist, lecturer and writer who lived across the 19oos, once suggested to 'buy land, because they are not making it anymore'. His affirmation, which could appear intuitive and banal, contains a fundamental truth which is often forgotten when agricultural development is studied and discussed. Land undoubtedly is a scarce resource, along with a fundamental element in the life of human beings, animals and plants. Disposing of land, granting concessions over it,

6) D. Harvey, The New Imperialism (Oxford University Press, Oxford, 2003).

7) S.M. Borras, D. Carranza and J. Franco, 'Anti-Poverty or Anti-Poor? The World Bank's Market-Led Agrarian Reform Experiment in the Philippines', in S.M. Borras (ed.), Market-led agrarian reform: critical perspectives on neoliberal land policies and the rural poor (Routledge, Abingdon, 2008). 
enclosing its boundaries, or any other political decision concerning it, automatically determine the increase or reduction in the availability and accessibility to the resource by any living being on earth. As a consequence, it is possible to affirm that the different forms of land governance, the ways in which authority is exercised, and the level of accessibility which is granted, go beyond the people directly involved, and can produce deep social, cultural and economic consequences. However, the state as representative of the collective certainly is a crucial actor in the ongoing rush to African land, which is mainly characterized by the enclosure of thousands of hectares in favour of individuals, the reduction of the land publicly accessible, and the transformation of the forms of production from people intensive to capital intensive.

According to the most recent studies on land grabbing in Sub Saharan Africa, in fact, it is possible to affirm that the projects of agricultural development through large scale investments in land are mainly undertaken through the direct involvement of the state, which exercise its authority to dispose of the land in favour of the investors. In particular, there are two kinds of 'public land grabbing', both of which involve the direct participation of the state to support the investment. On the one side, a huge number of projects concern land which is defined as "public or national,"8 but it is also common to run across projects where privately or collectively owned land is expropriated in the name of public interest.

In particular, numerous African constitutions, shaped on the colonial idea of 'eminent domain' and on a system of centralized land governance, provide a clearcut distinction between titled land and untitled land, being the latter under the full control of the state, who has the duty and the right to exercise its coercive power in the public interest of his citizens.

Starting from the latter case, the state reinforces its full authority over its territory and land, which is considered legally empty and, therefore, fully disposable. According to the legal framework which is shared by several countries in Sub Saharan Africa, occupants of an area who lack any form of formal legal title are considered no more than mere possessor, a situation that increases uncertainty and their dependency from states' actions. In these circumstances, public authority can be exercised, with a broad margin of discretion over these territory and their occupants. ${ }^{9}$

Paradoxically, a legal scenario introduced in the post-colonial period with the intention to utilize the public domain as a form of protection of the local population from the excesses of private appropriations and forced evictions, is now providing public and private actors with an undisturbed access to land and water. In the last years, thousands of people have been considered as illegal squatters on

\footnotetext{
8) L. Alden Wily, The tragedy of public lands: The fate of the commons under global commercial pressure (International Land Coalition, Rome, 2011).

9) Ibid.
} 
the land that their communities have been inhabiting for centuries, and evictions enforced without any free, prior and informed consent - nor consultation -. When required to intervene to protect their citizens rather than evicting them from their houses, government defend themselves behind the idea that 'the people are to blame for settling on the land and not respecting the courts', and conclude that they 'will not help in anyway, [and that] the villagers have to find a solution to the problem'. ${ }^{10}$

Similarly, even when a different legal architecture is in place, and property titles are officially recognized, states have been actively involved in the production of justification for expropriations and evictions, which are usually contained in the declaration of 'public interest' or 'public necessity'. Creating a dangerous equation between economic growth and public interest/necessity, or considering that the internal problems of their countries depend exclusively on the lack of foreign investors, states have been transferring land from communities to individuals, all under the cover of law. Land ownership and the existence of a title become, therefore, a trivial obstacle when compared to the exercise of sovereign authority and the extension of the legitimate coercive power of the state as it is legally exercised by the (often democratically elected) people's representatives.

As in the case of Ethiopia which has been recently studied by Human Rights Watch ${ }^{11}$ or in the cases of Philippines described by Saturnino Borras, people have been removed from their houses, their huts have been destroyed, and alternative shelters, when realized, have been improperly built or located. ${ }^{12}$ In all these cases, states are not defending the existing relationship of people inhabiting and working the land, but rather exercise their authority in order to freely dispose of public land in favour of non-owners, who often are foreigners with no previous relationship with land and the community.

In both circumstances, a legal system which concentrates power in public authority becomes the perfect platform for the enforcement and realization of the ideology of economic growth and industrialization. Law and economics become, in this light, mutually supportive and reciprocally reinforce in the attempt to pursue a specific goal. The primacy of modernity and the dream of an African green revolution are endorsed by the nation states, which maximize their internal power in order to transform their land scenario in a way which is functional to the interests of the investors, i.e. by clearing it from any legal or physical encumber.

\footnotetext{
10) Declaration of Richard Hara, Mzuzu City chief executive, concerning the eviction of people after they lost a land dispute concerning occupied land in Choma, Mzuzu, Malawi. Cf., G. Singini., 'No help for squatters', The Nation, Wednesday January 2 th 2013.

11) Cf., Human Rights Watch, What Will Happen if Hunger Comes?: Abuses against the Indigenous Peoples in Ethiopia's Lower Omo Valley, (Human Rights Watch, New York, NY, 2012).

12) This scenario presents several similarities with what normally happens in the case of the construction of mega-development projects like dams, roads, or mines. As in all these cases, LaSIL are characterized by the paradoxical tension between the official proposal to provide people with food and better life conditions, and their eviction. Cf. Human Rights Watch, ibid.
} 
Whether land is considered public or privately owned, people who live in the area are forced to give space to the investors, whose primary interest is to have access to land which is empty both from a physical and from a legal point of view.

However, whether some attention has been paid to large-scale investments as directly linked to expropriation and eviction of recognized owners, ${ }^{13}$ almost no legal and social analysis has been developed with regards to the evictions that take place from public land where occupiers are treated as illegal squatters. However, this latter situation, which is closely linked to the enactment of pro-industrialization land reforms or to conclusion of investment contracts by the representatives of a state, appears even more controversial. By enforcing a form of democracy that closely resembles the dictatorship of the majority over the excluded minority, states voluntarily produce exclusion and marginalization, in the supposed interest of the collectivity. Farmers and peasants are suddenly transformed in squatters on land that belongs to the entire community, and become illegal occupiers who are ready to be legitimately evicted without confrontation nor compensation. For that reason, the next paragraph is dedicated to a deeper understanding of the legal architecture and the procedures that give the state the opportunity to exercise its authority over public land as eminent domain, so that it can legally evicts its occupiers.

\section{The Damocles' Sword of Public Land}

According to the latest report by the World Bank, Sub-Saharan Africa disposes of an agricultural potential equal to 201761 million hectares of uncultivated land that can be used to produce sugar cane, maize, palm oil or soybeans, is not covered by forests and has a density of less than 25 habitants per $\mathrm{km}^{2} .{ }^{14}$ However, a different reconstruction is provided by anthropological and sociological studies conducted on the availability of land by listening to the voices of the people.

These latter reports, much less popular than their alter-ego, affirm that underutilized or void land in Sub-Saharan Africa does not exist, at least not according to the local conception of property and utilization. However, national legal orders and legislator seem to believe more in the interpretation given by the World Bank and other multilateral institutions. Currently, more than $70 \%$ of African land is non-titled, so it formally belongs to the nation state rather than being officially and legally attributed to the people and communities who live it, work it, and in many cases preserve it for future generations..$^{15}$

\footnotetext{
13) Ibid.

14) K. Deininger, D. Byerlee, J. Lindsay, A. Norton, H. Selod and M. Stickler, Raising global interest in farmland (World Bank, Washington, DC, 2011).

15) L. Alden Wily, 'Looking Back to See Forward: The Legal Niceties of Land Theft in Land Rushes', 39 Journal of Peasant Studies (2012), 751-775.
} 
Therefore, thousands of African communities, equivalent to millions of people, are currently living and farming land which is not formally theirs, because they did not receive a title when land reforms were realized. This legal scenario, which is common to many states included Sudan, ${ }^{16}$ Chad, DRC, Somalia, Zimbabwe, Burundi, Liberia and Tanzania, ${ }^{17}$ appears to be the file rouge of the post-colonial Sub Saharan land regime. Interestingly enough, if we look at the rationale behind the political choice of reinforcing public land over private ownership, we can easily understand the existing paradox. Public ownership that was supposed to be a source of democratic defense and people's empowerment against accumulation and exclusion, has been transformed into a mechanism of private appropriation of common spaces by the use of public prerogatives, and of consequent displacements.

Constitutional provisions that were presented as a way to protect communities from being expelled and dispossessed, have now become an instrument in the hands of economic globalization, a legitimate tool to guarantee easier access to natural resources by few individuals, to the detriment of the multitudes. Today, to live on public land does not mean to be secured and protected by the strength of the state, but rather to risk to be considered an illegal occupier who has to be detained and forcedly removed.

Evictions in the name of development have been undergoing everywhere in the African continent, ${ }^{18}$ and the judicial cases of the Endorois in Kenya ${ }^{19}$ and of the Amuru in Uganda ${ }^{20}$ demonstrate that it exists a legal incongruence between the public ownership and the occupation by the rural communities. On the one side, states reclaim the power and legitimacy to define the limits of internal legality, and consequently to enclose land which is not utilized or to evict whoever is considered an illegal occupier. On the other side, communities who have been living in the area for hundreds of years, who have rooted their culture and buried their dead ancestors, cannot do anything else than reclaiming their traditional right to land which does not formally belong to them. And even if the African Commission on Human and People Rights has adopted a protective position in

\footnotetext{
16) Unregistered Land Act, 1970.

17) Alden Wily (2011), supra note 8.

18) One of the latest cases concerns the realization of the Gibe III hydropower project and of the 'Sugar Block One' agricultural development in the Lower Omo Valley, Ethiopia. The full implementation of which could affect at least 200000 people in the Omo valley and another 300,000 Kenyans living across the border around Lake Turkana, which derives up to $90 \%$ of its water from the Omo River. Cf., Human Rights Watch, ibid.

19) Endorois Welfare Council v. Kenya [2010] AfCHPR. The case was filed by members of the Endorois people that had been evicted by the government in order to undertake a project of touristic development in Kenya.

20) Case heard by the Gulu High Court, in Northern Uganda, February 2012. The case concerns 40 ooo hectares of land in the North of Uganda, in the Gulu Region, that have been assigned by a district land board to Madhvani Group Ltd. in order to implant a sugar factory.
} 
favour of people whose traditional property title had not been recognized, ${ }^{21}$ there is little certainty that national courts will be of the same advice. ${ }^{22}$

This ambivalent situation is derived, I argue, from a conflict between the legal pluralism of the ground and the supra-imposition of exogenous homogeneous legal concepts such as nation state, sovereignty, and the duality between public and private. As several post-colonial scholars have argued, the legal array of modernity is not only inappropriate for places and people who do not share Western history and culture, but has also the negative effect of dismantling legal diversity and weakening peoples' security. The adaptation and translation of Western institutions in the scenario of post-colonial Africa has been, in fact, appropriated by political and economic elites (within and outside the countries) and functionally utilized to reproduce the colonial system of exclusion and marginalization.

However, it is not exclusively a matter of misappropriation of public authority. As extensive literature has demonstrated, ${ }^{23}$ land titling and attribution of private property do not represent the panacea, unless the process is conducted in an pro-poor way that does not impose external legal institutions nor crystallizes the existing power asymmetries. In particular, titling can be another source of accumulation and indirect displacement, but also a strategy to penalize the weakest and reinforce the patriarchal nature of specific societies.

In conclusion, enclosures, evictions and migrations are not always and not necessarily the consequence of a formalized process of expropriation and expulsion.

On the contrary, in a situation where $70 \%$ of the African land is embedded in the legal limbo between the formality of public land and the customary nature of the commons, displacement is a direct effect of the exercise of public authority to define the land void and available. As several cases demonstrate, states receive from their constitutions the coercive power to declare traditional occupancy as legally inexistent (or illegal), and to prevent people from accessing or returning to their ancestral land.

21) The African Commission has stated that 'traditional possession of land by indigenous people has the equivalent effect as that of a state-granted full property title and that traditional possession entitles indigenous people to demand official recognition and registration of property title.

22) Referring to Uganda's Land Act of 1998, the Gulu High Court has found that the contested territory was unoccupied public land and hence fell under the control of the district land board.

23) See, e.g., P. Hirsch, Titling against grabbing? Critiques and conundrums around land formalisation in Southeast Asia, Paper presented during the 2011 International Conference on Global Land Grabbing, ILDP, University of Sussex; S. Borras and J. Franco, 'Towards a broader view of the politics of global land grab: rethinking land issues, reframing resistance', 1 Initiatives in Critical Agrarian Studies Working Paper Series (2010), 1-39; S. Borras and J. Franco, 'Global Land Grabbing and Trajectories of Agrarian Change: A Preliminary Analysis', 12 Journal of Agrarian Change (2012), 34-59; E. Field and M. Torero, Do property titles increase credit access among the urban poor? Evidence from a nationwide titling program (IFPRI, GRADE, Washington, DC, 2004); K. Kanyinga, O. Lumumba and K.S. Amanor, 'The struggle for sustainable land management and democratic development in Kenya: a history of greed and grievance', in K.S. Armano and S. Moyo (eds), Land and sustainable development in Africa, 1st edn (Zed Books, London, 2008), pp. 100-126; N. Kligerman, Alienation in Acholiland: War, Privatization, and Land Displacement in Northern Uganda, ISP Collection, Paper 675 (SIT, Brattleboro, VT, 2009). 
In this scenario, rather than an unlikely convergence of judicial approaches between the African Commission and the national courts, the solution appears to lie in the exercise of political prerogatives to undertake a widespread reform of the tenure systems. However, without the right incentives it appears extremely difficult that sovereign states will renounce to the power and authority that derive from the direct control over the majority of African land. For that reason, it becomes essential to stress the negative impacts that large scale investments in land can have over the life of citizens, and raise internal and international awareness. Only when the chiasmus between formal property and informal occupation will be solved, and when occupation will be legally recognized in order to guarantee normative goals as equity, sustainability and accessibility, the relationship between people and land will be finally protected, and communities will be free to fully express themselves. Otherwise, governments will continue to sign contracts where they treat land as their own property, and people described as mere burdensome encumbrances.

\section{Contracting the Eviction}

The immediate consequence of the coexistence between the recognition of eminent domain over the majority of Sub Saharan Africa as the predominant legal regime and the continuous pressure of global capital to access land and satisfy the increased need of food and energy, is the exclusion and marginalization of people that takes place through the conclusion of contractual agreement between states and investors.

From a strict legal perspective, investment contracts in land are nothing but private agreements, but the special characteristics of the state as sovereign entity have the effect to transform their content into binding law. In this way, the substance of a private agreement becomes a coercive instrument in the hands of states and investors that can redefine the borders of legality and property, along with the life of the people.

In particular, investment contracts represent the most diffused way to enhance industrialization in occupied land, i.e. to directly dispose of public land and displace its occupiers, mainly because of the difficulty to enact land reforms and due to the private nature of the agreements. Among the most recent examples of the use of private contracts where public land has been given in concession without consultation and the existence of people transformed in an illegal occupation, there are the cases of the tree plantation project by the New Forest Company in Uganda, ${ }^{24}$ the 100 ooo hectares of concession obtained by Malibya-Agriculture from the government of Mali, the 300 ooo hectares investment by Karuturi Group

24) A case related to the evictions that took place in order to guarantee the installment of the New Forest Company project of trees plantation has been filed by the local communities and is currently under 
Ltd. in Ethiopia, ${ }^{25}$ and the palm oil project undertaken by SG Sustainable Oil Cameroon PLC. ${ }^{26}$

In addition, not only states and investors conclude an agreement according to which occupied public is legally defined as void and available, but they also assume duties or rights to intervene in order to guarantee the effectiveness of the contract. In the above mentioned cases, the state, instead of defending the prerogatives of its citizen over their ancestral land, assumes the obligation to deliver free and empty land, i.e. to get rid of any existing obstacle to private exploitation. The effective presence of people and the existence of a long lasting relationship between them and their territory are not guaranteed legal recognition and, therefore, not awarded any protection.

Instead of defining legality according to the bottom-up reality of communities, the contract defines and interprets the boundaries of law according to the economic paradigm proper of industrialization and accumulation, and this vision is then crystallized in an agreement that binds the present and future actions of governments.

In the name of the people, whoever represents the state in the conclusion of the contract accepts the idea of terra nullius as the legal frame of reference, and welcomes an investment contract that freezes this situation from a legal point of view. ${ }^{27}$ In particular, executive branches assume the obligation to 'hand over vacant possession of the land'28 or to 'ensure that such lands shall be free from Encumbrances at the date of handover of such lands in accordance which the Development Project'. ${ }^{29}$ By bringing together private interests and sovereign prerogatives, the narrative of empty land is therefore transformed into the legal reality that dismantles existing institutions, usages and customs, and that transforms people in encumbrances that have to be removed.

As in the case of land reforms which define land as public and unoccupied, in the moment where the contract is concluded and describes the land as empty or free, whatever differs becomes illegal, so that occupiers are suddenly transformed in property outlaws ${ }^{30}$ and can be the target of legitimate eviction and forced displacement. As occupiers with no title and no right, they could be converted into

investigation by the Office of the Compliance Advisor/Ombudsman of the International Financial Council. Cf., Oxfam, The New Forest Company and its Uganda Plantations (Oxfam, London, 2011).

25) J. Vidal, 'Ethiopia at centre of global farmland rush', The Guardian, (London, 21 March 2012).

26) S. Nguiffo and B. Schwartz, Herakles 13th Labour: A Study of SGSOC's Land Concession in South-West Cameroon (Centre pour l'Environnement et le Développement, Yaoundé, 2012).

27) F. Makki and C. Geisler, Development by Disposession. Land Grabbing as New Enclosures in Contemporary Ethiopia, Paper presented at the International Conference on Global Land Grabbing, 6-8 April 2011.

28) Article 6.1 of the contract concluded between the Ethiopian government and Karaturi Agro Products Plc. (R. Rowden, India's role in the new global farmland grab (Economic Research Foundation and GRAIN, New Delhi, 2011), p. 29).

29) Article 4.1(c) of the Liberia-Sime Darby Contract of April 2009.

30) E.M. Penalver and S. Katyal, Property Outlaws: How Squatters, Pirates, and Protesters Improve the Law of Ownership (Yale University Press, New Haven, CT, 2010). 
legal owners. However, the conclusion of the investment agreement transforms them into squatters on their own land, who can be legally evicted. Legality and illegality, emptiness and occupation, demonstrate their nature of blurred legal creations that are subject to interpretation and adaptation. They can be used as instruments to defend people and their traditional rights against private enclosures, or, as history is demonstrating, can be exercised to produce legal eviction, displacement, and migrations.

Thousands of people have already been removed from their land as consequence of contracts and land reforms, and many more will face the same faith. In the sole case of SG Sustainable Oil, in fact, more than 25 ooo people are currently living in land which the Cameroonian Ministry of Industry has attributed to the investor, and their destiny is everything but clear. ${ }^{31}$ In the name of development and economic growth, a formalistic and unilateral approach to property and land is adopted, which erases from the horizon both traditional relationships and customary rights. And, interestingly enough, that does not only happen when a public reform is enacted, but also when private contracts are signed.

Moreover, some of the contracts go even beyond the non-recognition of legal occupation and the introduction of the duty for the state to evict whoever is found within the designed area (which is found is the majority of the analysed contracts). If we read the agreement concluded between SG Sustainable Oil Cameroon PLC and the Ministry of Energy, Planning and Legal Development PLC, we find that article 9.3 states that 'Government hereby authorizes Investor directly or under contract with other Persons of its choosing, to establish, manage and maintain its own asset and employee security and protection service [...] such service shall have the power to search, apprehend, detain, exclude and evict unauthorized Persons from the Production Area, and from such other areas as may be properly restricted for economic, operational or security reasons, subject to applicable Law". ${ }^{32}$

If the applicable law is the investment contract, everyone who happens to be in the production area can be apprehended, detained, excluded and evicted by the investor. In a complete reversal of the traditional power relationships, and in a complete dismissal of sovereign prerogatives, the use of legitimate coercive power to displace and evict ceases to be an exclusive prerogative of the state, and is fully attributed to the private investor, who becomes the new official authority.

In this way, the finality of the contract is not only to formalize the investment and guarantee unlimited access to natural resources, but becomes a way to replace the public with the private through the transfer of authority which legitimizes the

31) Nguiffo and Schwartz, supra note 26.

32) Establishment Convention between the Republic of Cameroon and SG Sustainable Oil PLC, Article 9.3, available online at http://cameroonveritas.wordpress.com/ (accessed 8 December 2012). 
exercise of private violence against communities. The exclusionary and privatizing paradigm of modernity is accomplished, and people are the victims.

Finally, it is worth noticing another existing paradox. International public law, rather than providing protection and defence to the people, becomes an overarching form of legal oppression, the deadly machine described by Mattei and Russi. ${ }^{33}$ Given the fact that the majority of the contracts are submitted to umbrella clauses and Bilateral Investment Treaties that require the application of international law in case of any violation of the agreement by the state, the latter is not only bound by the contractual obligation, but by a system of international law which is normally enforced by means of investment arbitration. In this way, the 'internationalization' of the private deals reinforces new legal hierarchies that subordinate collective needs to the private interests of the investors, and that constraints the use of coercive power in an exclusionary way. As a paradigmatic moment of conjunction between the sovereign prerogatives over the land and the private interests of the capital, investment contracts become the new source of public law and legitimate violence: capital is ready to wear the police uniform, and push people out of their land.

However, it is sufficient to reflect on the relationship between large scale investments and the underlying social structure to realize that the incompatibility between mass agricultural industrialization and rural livelihood is not reduced to those projects where there are overlapping interests and legal claims between states, investors and local communities. As the next Section shows, that largescale investments in sub-Saharan land are affected by the inherent exclusionary character of modernity which has been eloquently described by Arturo Escobar. ${ }^{34}$ Industrialization not only affects the environment and the conservation of natural resources, but has an economic and social impact over peasantry which requires a deeper analysis of its availability as a means of inclusive and equitable development.

\section{Large-Scale Investments as Inherent Sources of Socio-Economic Exclusion}

The analysis of the different forms of land grabbing that has just been presented demonstrates that law and sovereignty play a crucial role in the 'territorialization' of the project of modernity, and in making it global. Moreover, it has cast some light on the exclusionary nature of large-scale investments as direct sources of land grabbing and development-driven displacement. Whether land is expropriated in the name of economic development, or considered void or underutilized,

33) U. Mattei and L. Russi, "The Evil Technology Hypothesis: A Deep Ecological Reading of International Law', Cardozo Law Review de novo (2012), 263-277.

34) A. Escobar, Encountering development: the making and unmaking of the third world (Princeton University Press, Princeton, NJ, 2012); W. Mignolo and A. Escobar, Globalization and the decolonial option (Routledge, Abingdon, 2010). 
the adhesion to the specific model of large-scale industrialization inevitably produces enclosure, marginalization, subtraction of land, and displacement that in the short of long-term can prevent people from achieving some of their fundamental rights.

However, the risks and injuries for rural people and peasants which derive from the political acceptance of large scale investments as the way to go are intensified by some features which are proper to this specific kind of land projects, whose impacts are mainly visible in the long term. These elements, which are often overlooked when the projects are discussed and proposed, force a serious reconsideration of the capacity of LaSIL to generate positive effects for the local communities, along with the possibility to consider them as effective instruments of social development. In a finite and competitive world like ours, where land and water are essential and scarce resources, the coexistence between the big fish of agroindustry and the small fish of peasantry is, in many cases, Utopia.

As a consequence, statements like those recently formulated by Mozambican Agriculture Minister Jose Pacheco that "In our country there is no place for the return of crown companies" and that "The small farmers will keep their land" do not represent a real insurance for the permanence of peasantry in the area, and mislead our reasoning. ${ }^{35}$ If we exclusively focus on the short term and direct impact of the land transformation, we miss part of the picture, and do not fully understand the implications of the process. Previous and current experiences demonstrate, in fact, that the long term impact of large scale investments in land and the consequent industrialization can be even deeper and more pervasive than the 'sole' direct eviction and displacement that take place in the first phase. Moreover, if we limit our analysis and concerns to the immediate consequences, we cannot produce an appropriate consideration of the efficiency and desirability of the project. Finally, if we accept to the short-term perspective, we will be claiming for the responsibility of the state to mitigate and compensate the damages produced by the land conversion and the enclosure, and we will celebrate whenever we observe public consultation, economic contributions, and the respect of the existing procedures. However, the existence of long-term and indirect consequences (mainly triggered by unequal and unfair competition for resources and market), goes beyond the simple respect of the procedures, and concerns the compatibility and coexistence between conflicting economic and social paradigms. If we forget that and narrow the notion of responsibility to the immediateness of the direct violation, we eventually legitimize long-term violations conducted in the respect of the existing procedures, and reduce the possibility of future confrontations.

35) All Africa, 'Mozambique: "Pro-Savana" will not deprive farmers of land', AIM (26 December 2012); 'O que quer o Brasil com o ProSavana?', ADECRU (24 March 2013), available online at http://adecru.wordpress.com/2013/03/24/o-que-quer-o-brasil-com-o-prosavana/ (accessed 24 November 2013); 'ProSavana: Brasil banca usurpação de terras em Moçambique', Viomundo (14 June 2013), available online at http:// www.viomundo.com.br/denuncias/prosavana.html (accessed 14 June 2013); Note deleted for anonymity. 
For these reasons, it becomes extremely important to focus on the intrinsic incompatibility between large-scale agricultural production, the survival of peasantry, and the wide availability of scarce resources. In particular, it seems that there are at least five arguments that support the thesis of large-scale investments in land are inherently exclusionary:

(a) Historical: if we look at the history of humanity, we realize that enclosures, large-scale investments in land and industrialization have generated exclusionary effects everywhere they have been applied. It certainly was the case of the industrial revolution, but the same short and long term processes can be traced as a consequence of the industrialization of agriculture in the United States, Brazil, and, as a by-product of the Indian Green Revolution. ${ }^{36}$ In all these cases, the increased yields, economic growth, and the technologies to produce them, were aimed not at the small farmers, but at commercial ones, i.e., those who already disposed of economic and political resources, and who consolidated their position to the detriment of the rest of the peasants. When Minister Pacheco affirms that 'We want these small farmers to become commercial farmers on a small, medium and eventually even large scale', we should thus realize that only few farmers will effectively have that chance, and they will hardly be the weakest and most marginalized;

(b) Capital v labour: as a percentage, capital-intensive agriculture employs less people than labour intensive one, which means that not all households can find employment, and consequently need to displace to find new available land or move to the city. For example, the 2006 Agrarian Census conducted by the Instituto Brasileiro de Geografia e Estatistica (IBGE) over Brazilian agriculture, the institute concluded that agrobusiness only employs 1.7 people per 100 hectares, while small-scale farming gives jobs to 15 people. ${ }^{37}$ Moreover, a scenario with 'some degree of land and a lower percentage of total employment involved in direct agricultural production', i.e., the reduction of rural population involved in agriculture and its urbanization, is presented by the Gates Foundation and the World Bank as an inevitable and inherent consequence of the New Green Revolution, although their long-term consequences in terms of economic, social and political impact are not assessed. ${ }^{38}$ The real impact of 'Brazilian agricultural miracle', which is presented in some African countries as the model for future growth and economic development requires, therefore, to be better understood and more truthfully described;

36) R. Patel, 'The Long Green Revolution', 40 Journal of Peasant Studies (2013), 1-63.

37) Source Instituto Brasileiro de Geogràfia e Estatistica, available online at http://www.ibge.gov.br/ home/ (accessed 20 November 2013).

38) Cf., B. White, S.M. Borras Jr., R. Hall, I. Scoones and W. Wolfordm, 'The New Enclosures: Critical Perspectives on Corporate Land Deals', 39Journal of Peasant Studies (2012), 619-647. 
(c) Air and water pollution as a source of indirect displacement: another longterm consequence of industrialization is represented by the contamination of the available resources, mainly by means of water, land and air pollution. This circumstance raises two main concerns: it can only be registered some years after the beginning of the agricultural activities; once pollution has reached certain levels, it is extremely difficult to reverse the process, so that the contaminated resources become unusable for agricultural or other goals, but also source of great danger for the local communities. Leaving aside the health risk linked to water contamination by fertilizer, the impact of high levels of pollution are also economic, as demonstrated in the case of the Brazilian area of Lucas do Rio Verde, Mato Grosso. The research conducted by Carneiro et al. demonstrates, in fact, that the high level of fertilizers utilized on 420 ooo hectares of industrialized fields, produces 'toxic rains' which burns all the plants which are not resistant to the fertilizers, and penetrates in the water, reducing its availability and increasing its price. ${ }^{39}$ As a consequence, peasants have been obliged to find new available areas to produce their medicinal plants and food crops, and some of the inhabitants have abandoned the area due to the risk for people's health, but also because of the excessive cost of obtaining drinkable water. Some decades after the 'agricultural revolution of Mato Grosso', indirect consequences and underestimated implications are emerging, which mainly impact small scale farmers and the poorer members of the society.

(d) Competition in the market: independently from the crop which is produced on an intensive scale, and independently from the market of destination, industrialized production destabilises the local market and the economic capacity of peasants, so that the former are easily pushed out of their land, sometime even beyond the national borders. The existence of an asymmetry between the costs of industrial and small-scale production can degenerate into unfair competition between the products originating from the two different agricultural models, so that industrial products are likely to price rural farmers out of the market. In SubSaharan African countries food might be cheaper, but also produced by fewer people. As a consequence, in a region where the vast majority of the population is composed by small-scale farmers, that would generate an unprecedented wave of unemployment, with the consequent need to migrate or urbanize. Moreover, the shift from a multiplicity of producers to a concentrated number of farms will increase the risk of famine and the level of dependency from the global market, two conditions that are certainly incompatible with the idea of large-scale investments as a means to achieve diffused development. Equally, if land is utilized to satisfy external demand or to produce cash-crops for foreign markets, the amount of food available in the country will be drastically reduced, so that famine and

39) F.F. Carneiro, W. Pignati, R.M. Rigotto, L.G.S. Augusto, A. Rizzolo, N.M.X. Faria, V.P. Alexandre, K. Friedrich and M.S.C. Mello, Dossiê ABRASCO - Um alerta sobre os impactos dos agrotóxicos na saúde. Parte 1 - Agrotóxicos, Segurança Alimentar e Nutricional e Saúde (ABRASCO, Rio de Janeiro, 2012). 
hunger will be intensified, forcing people to look for new opportunities outside their original community, mainly through urbanization or long-distance migration. Whatever is produced on a large scale, and wherever the products are sold, industrialized agriculture and small-scale farming are economically incompatible, and in the long term the weaker player will be forced to leave her land. Moreover, the case of India, where every 30 minutes a cash-crop small-scale farmer commits suicide ${ }^{40}$ demonstrates that the value chain may produce wellbeing and economic stability, but has the potential to generate a wider set of negative consequences for smallholders that are often overlooked. ${ }^{41}$

(e) Competition for the resources: in the current framework, the increasing pressure over land is such that even in those cases where a short-term coexistence is possible, it will certainly become long-term incompatibility. In particular, large-scale projects trigger an internal competition between farmers and agroindustries for land and parallel resources - mainly water and fuel -, but also for the preservation of the habitat for plants and animals. If the state adopts an economic perspective and allocates the resources on the basis of the economic availability, it is evident that the beneficiary will not be the lowest stratum of the society, but whoever already has a certain economic availability. Moreover, we cannot underestimate the long-term impact of climate change, increased democratic pressure, higher level of meat consumptions, and other exogenous factors that will reinforce the already existing competition for land, so that the pressure exercised by investors over governments and people will become even more oppressive. If the global demand for food, meat and agrofuels will continue to surge, investors and agrobusiness will have stronger incentives to access more land and transform it into large-scale businesses.

In conclusion, whether Sub Saharan land is expropriated, declared void, or exposed to raising competition between rural and commercial farmers, in a region where population increased from 230 to 860 million between 1960 and 2010, where the average cultivated are amounts at 0.3 hectares per capita, ${ }^{42}$ and which is pressured by global demand for more land and intensive production, the paradigmatic shift from small-scale farming to industrialized exploitation will inevitably affect the poorest and most vulnerable and marginalized segments of the populations. The history of enclosures, green revolution and industrialization shows that

\footnotetext{
40) Center for Human Rights and Global Justice, Every Thirty Minutes: Farmer Suicides, Human Rights, and the Agrarian Crisis in India (NYU School of Law, New York, NY, 2011).

41) According to the report, 'It is estimated that more than a quarter of a million Indian farmers have committed suicide in the last 16 years - the largest wave of recorded suicides in human history. A great number of those affected are cash crop farmers, and cotton farmers in particular. In 2009 alone, the most recent year for which official figures are available, 17638 farmers committed suicide - that's one farmer every 30 minutes'.

42) International Fund for Agricultural Dev., Doc. EB 2008/94/R.2, Policy on Improving Access to Land and Tenure Security (2008), p. 17.
} 
migrations, mainly intra-regional, represent the solution to present or perceived risks. It would be enough to look back to avoid the same mistakes. ${ }^{43}$

As a matter of fact, it appears clear that, even without the abusive uses of sovereignty described above, millions of people will be indirectly excluded from and by the process of industrialization and modernization of agriculture. They will be prevented from having access to land and other resources, they will see their water polluted and their crops burnt by fertilizers, they will lose their market and their daily food ratio, so to be driven to urban centres and abroad.

Paradoxically (or not), large-scale projects that are promoted as the solution to global hunger and land degradation, will generate abandonment of the land, mass urbanization and uncontrolled growth of urban areas, three contingencies that are well known in industrialized countries and that are often used to justify foreign direct investments in Sub-Saharan land. In a scenario where law legitimizes exclusion, it is hard to affirm that law itself can provide alternatives and some tools of resistance. However, the coerciveness and absoluteness which are proper of sovereignty can be utilized as a shield to protect the communities from forced displacement.

\section{Which Forms of Legal Resistance? Titling, The Kampala Convention and the Need for an Immediate Moratorium}

One of the objectives of this paper has been to underline that any form of resistance against land grabbing and agricultural industrialization has to take into account both the short term and the long term consequences of this transformation. However, it seems that too many energies and efforts have been spent to obtain immediate accountability, leaving aside the political, economic and legal responsibility for the indirect consequences of such a radical conversion.

Facing the just described abuses of sovereignty by public authorities who consider the land as their own property, several authors have claimed that formalization of land titles can represent an effective protection of local communities and of their relationship with the land, mainly because it distributes land sovereign among the population, increases transaction costs and reduces the possibility of public land grabbing. However, market-led reforms undertaken in several Sub Saharan African countries are affected by some severe incoherencies that increase accumulation processes and displacement. Namely, (a) they often crystallize past dispossessions and formalize the existence of squatters that can thus be evicted; (b) they are based on the exercise of sovereign powers, which can be utilised to favour specific groups of interests rather than the collectivity in itself; (c) they are informed by a monochromatic vision of property as an individual commodity,

43) Alden Wily, supra note 15. 
a circumstance that deprives of legal power whoever does not receive the title; (d) they are based on the willing buyer-willing seller idea of parties' symmetry, without considering the existence of imbalances that facilitate concentration of land rather than its redistribution.

A second proposal, formulated by African and international authors, is that the African Union Convention for the Protection and Assistance of Internally Displaced People, signed in Kampala by eleven African States and entered into force on 6 December 2012, could provide the legal instruments to offset the negative impact of large-scale projects over internal displacement. As a matter of fact, Article 10 of the Convention specifically refers to 'Displacement Induced by Projects', providing a clear evidence of the close interrelation existing between modernization and forced mobility, and requiring that states 'shall prevent displacement caused by projects carried out by public and private actors.

However, although the Convention certainly represents a step forward in the protection of directly displaced people, it contains some fundamental and some lexical weaknesses that might paradoxically worsen the condition of rural populations affected by large-scale agricultural projects.

At first, the Convention does not forbid any displacement, but requires the State to prevent them 'as much as possible' and to 'ensure that the stakeholders concerned will explore valid alternatives': ${ }^{4}$ The formula is undoubtedly vague, and could be functionally abused by sovereign states according to the needs that they want to serve. Furthermore, the Convention requires State parties to 'carry out a socio-economic and environmental impact assessment or a proposed development project prior to undertaking such project', ${ }^{\prime 5}$ but does not introduce any specific requirement concerning the involvement of population, nor about their free, prior, and informed consent. In a situation where states have often cooperated with investors to the detriment of local farmers, the Convention seems to further expand the gap between people and authority. Thirdly, the Convention does not contain a mechanism of defence that can be directly triggered by the affected population, but relies on the action of sovereign states and the African Union as a whole. Forth, the Convention disposes that States simply have to provide monetary compensation for damages occurred to displaced people, without going as far as requiring the re-establishment of the previous life conditions, and without imposing any obligation over the investors. Not only this formulation attributes a price tag to displaced people and commodifies any aspect of their life, but it also appears extremely unlikely that it will be interpreted as imposing over the States the obligation to compensate non-material aspects of the displacement, such as the cultural and biodiversity losses produced by the forced removal from their

44) African Union Convention for the Protection and Assistance of Internally Displaced Persons in Africa, Article 101.1 (hereafter: The Kampala Convention).

45) Ibid., Article 103. 
ancestral land. ${ }^{46}$ Finally, despite the fact that avoiding forced displacements and evictions certainly represents a step forward, the Kampala Convention is completely silent when it comes to the responsibility and accountability of states for the indirect displacements generated by large-scale investments and industrialization. As I have said before, this narrow approach can be extremely dangerous, because risks to legitimize all those transformations conducted in the respect of the existing procedures, with no concern or political accountability for the indirect consequences that they can undoubtedly produce.

However, the conclusion is dedicated to the double nature of law and sovereignty, which, as a Damocles' sword, can certainly legalise direct and indirect displacements, but also offer some countermeasures. In any case, the objective of this paper is to stress the intrinsic incompatibility between large-scale investments and the continuation of peasantry intended as a small-scale, local, equitable and sustainable form of agricultural production. In light of what has been demonstrated, mitigation and adaptation do not represent acceptable strategies for achieving a diffused improvement of social and economic conditions of the lowest levels of the rural population, nor a second-best scenario.

For that reason, it is hard to claim that The Kampala Convention, the process of individual land titling, the use of extra-legal remedies such as corporate social responsibility or a traditional human right approach can provide the defence and security that vulnerable people require.

Beside a defensive strategy, a more holistic approach is required, which will be capable of tackling the root causes of land grabbing ${ }^{47}$ and to create an alternative paradigm, in particular concerning the continuous struggle between the mobility of capital and the immobility of sovereignty, the raising pressure over Sub Saharan land exercised by the need to satisfy the ideology of economic growth, and the continuous expansion of core economies (mainly the USA and Europe, but also the BRICS and other 'middle-income' countries) in the name of progress and modernity. ${ }^{48}$

\section{Conclusion}

Since the triple-F crisis of 2008, fertile land all over the world has been under growing pressure. The financialisation of the global market, the need to allocate capitals

\footnotetext{
46) Article $3(\mathrm{~g})(\mathrm{h})(\mathrm{i})$ of the Kampala Convention imposes over the State the obligations to ensure that individuals and non-State actors are held accountable for the production of internal displacements, for the causation of arbitrary displacement, and for the displacement produced as a consequence of economic and natural resources' exploitation.

47) S. Marks, 'Human Rights and Root Causes', 74 The Modern Law Review (2011), 57-78.

48) T. Ferrando, 'Land Grabbing Under the Cover of Law: Are BRICS-South Relationships Any Different?', in N. Bullard and D. Fig (eds), The Economic Rise of the South: A Critical Movement Reader (Transnational Institute, Amsterdam, 2014) (forthcoming).
} 
outside the traditional sector of speculation, and the rhetoric of guaranteeing the future security of the global population through further industrialization and the transformation to a global capitalist production, have found in peripheral land the target for increased investments and accumulation by dispossession. ${ }^{49}$

Until now, at least 80 million hectares have already been accessed by national and international investors, which have leased vast tracts of land to convert them into industrial production of export-oriented food crops and cash crops. Cooperative states, particularly in Sub Saharan Africa, have already determined the forced eviction of thousands of people, the majority of whom have not received any compensation because deprived of any title or considered as illegal occupiers of public land. In most of the cases, sovereignty and law provide governments with the right and legitimacy to pursue their objectives at the expenses of local population and the environment.

Rather than being fragmented and weakened, therefore, sovereignty appears to be essential for the project of modernity, because it produces 'legitimate illegality that happens within the borders of the rule of law and of democracy'. ${ }^{50} \mathrm{Gov}-$ ernments unilaterally create hierarchies between the different alternatives of development, favouring economic modernity over the alternative scenario represented by the support to local farmers and their conflicting vision of development. And that despite the fact that peasants and small-scale farmers represent more than 1.5 billion people in the world, and produce almost $70 \%$ of the global food production.

In a world were land is not infinite, large-scale projects are implemented over lands that are occupied, so that people are forced to relocate, and only seldom compensated for the loss of their livelihoods and the damages that they suffer. Through expropriation for public interest and evictions of pre-existing occupiers, states actively participate in the great transformation of the Sub Saharan society into a commodified market for land and goods, ${ }^{51}$ mainly because the realization of large-scale investments is geographically and legally incompatible with the existence and rights of local populations.

Moreover, the present article has suggested the need to produce a new intellectual effort that not only focuses on the short-term impact of large-scale land acquisitions over the life of the informal occupiers, bur that takes into consideration the long-term effects of the impossible coexistence between small-scale and commercial exploitation of land and other natural resources. Even when the projects are developed without generating any immediate displacement, in fact, their inherent characteristics make them incompatible with rural livelihood and

\footnotetext{
49) Harvey, The New Imperialism, supra note 6.

50) C.A. Rodríguez Garavito and B. de Sousa Santos, Law and globalization from below: towards a cosmopolitan legality (Cambridge University Press, Cambridge, 2005).

51) K. Polanyi, The Great Transformation: The Political and Economic Origins of Our Time (first published 1944, Beacon Press, Boston, MA, 2001).
} 
capable of producing negative effects that go beyond national borders. This is, I claim, the inevitable effect of the economic inequality between the actors, which will make farmers lose because of the increase consumption of essential resources by industrial actors, the raising pollution of the environment due to the consumption of oil and fertilizers, the menace to biodiversity and nature deriving from mono-cultures and cash crops, and the surging pressure over fertile land as a consequence of agrofuel policies and the change of food habits.

If we look at the past experiences of agricultural transformation conducted in the name of capital and modernity, they provide us with examples that should make us reflect on the choice of large-scale investments in land as an inclusive and sustainable means for development. Among the best known are the urbanization after the British enclosures at the end of the 18th century, the migrations after the sale of African land to European companies at the beginning of the last century, the Indian Green Revolution in the second part of the same century, ${ }^{52}$ and millions of people resettled as a consequence of the megadevelopment projects financed by international and national authorities in the last 30 years. ${ }^{53}$ All these cases demonstrate that modernization and industrialization are inherently linked with direct and indirect displacement, social unrest, discontent, exclusion and a deep reconfiguration of rural societies. ${ }^{54}$

In conclusion, we have to take history seriously, be aware of the inevitable relation between large-scale investments and displacement, both internal and international, and project our thoughts beyond the procedural violations during the resettlement processes, the preservation of farmers' land next to an industrialized area, and at the calculus of the compensation's entity.

In this optic, this article has tried to open the reader's eyes on a series of local problems that can easily become globally relevant. Economic approaches put a tag on people's land and on their sufferance, but can hardly cope with the dismantlement of cultural diversity nor internalize the long term effects produced by the increasing replication of industrialization as a subtle and indirect form of socio-economic disruption and eviction. Relocations, displacements and massive urbanizations are happening before our eyes, but the impact of the current surge in large scale investments in Sub Saharan African land can go far beyond that: And we certainly cannot wait until the day when, looking back in disarray, we'll ask ourselves how everything began.

\footnotetext{
52) The Indian "Green Revolution" demonstrates that the passage from subsistence farming to intensive exploitation exponentially increases the need for water, which is therefore diverted from domestic to agricultural uses. Cf., Patel, supra note 36 (claiming that the change of economic paradigm, therefore, can ease droughts and famines, even when 'land degradation, access to water and food and human health remained at the centre of global attention under the debate on the World Summit on Sustainable Development').

53) S. Kothari, 'Whose Nation? The Displaced as Victims of Development', 31 Economic and Political Weekly (1996), 1476-1485.

54) H. Bernstein, Class dynamics of agrarian change. Agrarian and Peasant Studies Series (Rernwood, Halifax, 2010); E. Hobsbawn, The age of revolution. Europe 1789-1848, (Abacus, London, 1962).
} 